\author{
ANDRZEJ CHUDNICKI \\ Uniwersytet Marii Curie-Skłodowskiej w Lublinie
}

\title{
REFORMA SYSTEMU PIECZY ZASTEPCZEJ. ZAŁOŻENIA, RZECZYWISTOŚĆ, PERSPEKTYWY
}

\begin{abstract}
Abstrakt: Celem artykułu jest przedstawienie zmian, które zaszły w XXI wieku w polskim systemie instytucjonalnej opieki nad dzieckiem. Omówione zostały przekształcenia instytucji opiekuńczo-wychowawczych w kontekście ogólnoświatowych tendencji w zakresie przejścia od opieki instytucjonalnej do opieki świadczonej na poziomie lokalnych społeczności. Wskazane zostały skutki dotychczasowych rozwiązań prawnych i organizacyjnych. Jako przyczynę niezmniejszającego się zapotrzebowania na opiekę instytucjonalną wskazano brak skutecznych rozwiązań w zakresie polityki społecznej, powodujący wzrost liczby małoletnich pod opieką sądów. Zaproponowana została również inna niż dotychczasowa organizacja instytucjonalnej pieczy zastępczej, uwzględniająca przede wszystkim potrzeby dzieci.
\end{abstract}

Słowa kluczowe: małoletni, piecza zastępcza, placówki opiekuńczo-wychowawcze

Opieka nad dzieckiem jest naturalną powinnością wynikającą z rodzicielstwa. Polega na wykonywaniu czynności umożliwiających utrzymanie przy życiu i prawidłowy rozwój własnego potomstwa, które z racji niedojrzałości psychicznej i fizycznej nie jest $\mathrm{w}$ stanie funkcjonować samodzielnie.

We wczesnych regulacjach prawnych władza rodzicielska miała charakter władzy absolutnej, nierzadko trwającej aż do śmierci rodzica lub dziecka. Regulacje prawne, traktując dziecko przedmiotowo, stawiały na pierwszym miejscu interes rodzica. $\mathrm{Z}$ upływem czasu normy prawne ewoluowały, by na przełomie XIX i XX wieku za najważniejsze uznać dobro dziecka. Zmiana ta pociągnęła za sobą konieczność zastąpienia pojęcia „władzy rodzicielskiej” innym określeniem, mniej akcentującym uprawnienia rodziców i bardziej wskazującym na ich powinności. 
Podporządkowanie dziecka rodzicom miało wynikać $\mathrm{z}$ ich autorytetu oraz relacji uczuciowych, a nie z przypisanej im władzy. Pojęciami, które we właściwy sposób oddawały charakter relacji między dzieckiem a rodzicami, okazały się: "piecza rodzicielska”, „odpowiedzialność rodzicielska” czy „troska rodzicielska” (Grobel 2014).

Bycie rodzicem oznacza zarówno prawo do decydowania o losie swojego dziecka, jak i posiadanie obowiązków wynikających z władzy nad drugim człowiekiem. Wiąże się to z przyjęciem określonej roli społecznej oraz realizacją związanych z nią oczekiwań społecznych i obowiązków. Naruszenie zbioru powszechnie uznawanych norm i reguł przez nieprawidłowe wywiązywanie się z przypisanej roli jest zachowaniem dewiacyjnym, które skutkuje reakcją wytyczających i utrzymujących te granice instytucji kontroli społecznej. W Polsce najczęstszą reakcją na niewłaściwe wywiązywanie się rodziców ze swoich obowiązków jest ingerencja sądu we władzę rodzicielską.

Sąd rodzinny na mocy przepisów kodeksu rodzinnego i opiekuńczego może rodzicom nieodpowiednio zajmującym się dziećmi odebrać, zawiesić lub ograniczyć władzę rodzicielską. Robi to przez zobowiązanie rodziców i dziecka do określonego postępowania, wskazanie czynności, które nie mogą być dokonywane bez zezwolenia sądu, poddanie wykonywania władzy rodzicielskiej nadzorowi kuratora sądowego lub skierowanie małoletniego do organizacji lub instytucji powołanej do przygotowania zawodowego albo do innej placówki sprawującej częściową pieczę nad dziećmi. Może również umieścić małoletniego w rodzinie zastępczej, rodzinnym domu dziecka albo w instytucjonalnej pieczy zastępczej.

Najczęściej stosowanym przez sądy rodzinne sposobem ingerencji jest ograniczenie władzy rodzicielskiej. Według danych Ministerstwa Sprawiedliwości spośród 210474 małoletnich będących w 2013 roku pod opieką sądów rodzinnych aż 86\% stanowiły dzieci, których rodzicom sądy ograniczyły prawa rodzicielskie. W 11\% przypadków sądy odebrały prawa rodzicielskie, a 1\% rodziców zawieszono prawa rodzicielskie. 2\% małoletnich pod opieką sądów stanowiły sieroty naturalne (Ministerstwo Sprawiedliwości 2014).

W ciągu 11 lat (do 2011 roku) liczba dzieci w Polsce zmniejszyła się o 23\% (a w stosunku do 1989 roku aż o 38\%). Niżowi demograficznemu oraz ujemnemu przyrostowi naturalnemu towarzyszy wzrost liczby dzieci znajdujących się pod opieką sądów (w latach 2000-2013 wyniósł 23\%). W 2000 roku dzieci w takiej sytuacji stanowiły zaledwie 1,9\% populacji. Dwanaście lat później wskaźnik ten wyniósł już 6\%.

Wzrostowi liczby małoletnich będących pod opieką sądów towarzyszy zwiększenie ilości osób zaangażowanych w pomoc dziecku i rodzinie oraz poprawa współpracy między instytucjami. Priorytetem zintegrowanych działań nakierowanych 
na rodzinę nie jest jednak jej wsparcie, lecz wykrywanie i zapobieganie przemocy. Statystyki policyjne wskazują, że w 2000 roku odnotowano 116664 przypadków przemocy domowej, z czego 23\% spraw przekazano do innych instytucji (przede wszystkim do ośrodków pomocy społecznej i gminnych ośrodków rozwiązywania problemów alkoholowych). W 2011 roku było niewiele mniej wykrytych przestępstw przemocy w rodzinie, ale innym instytucjom przekazano aż $90 \%$ spraw. Ilość zdarzeń zarejestrowanych w 2013 roku przez policję w procedurze Niebieskiej Karty wzrosła w stosunku do poprzedniego roku o blisko 10000 spraw (czyli o 20\%). Jako jedną z przyczyn przyrostu ujawnianych przypadków przemocy można również wskazać wprowadzenie w 2013 roku nowych kwestionariuszy do oceny ryzyka przemocy, co spowodowało wzrost liczby zarejestrowanych przypadków w okresie 2013-2014 o 42\% (policja.gov.pl). W tym celu zostały powołane zespoły interdyscyplinarne, w skład których wchodzą przedstawiciele różnych profesji ściśle współpracujący z wymiarem sprawiedliwości. Obowiązkiem osób, które w toku czynności służbowych otrzymały informację o przemocy w rodzinie, jest powiadomienie o tym fakcie organów ścigania. Dodatkowo pracownicy socjalni zyskali uprawnienia wynikające $\mathrm{z}$ art. 12.a.1 ustawy o przeciwdziałaniu przemocy w rodzinie pozwalające na odebranie dziecka w przypadku stwierdzonej przemocy (ustawa z dnia 29 lipca 2005 r. z pózn. zm.). Liczba dzieci trafiających w ten sposób do placówek opiekuńczo-wychowawczych stale wzrasta. W 2011 roku pracownicy socjalni odebrali opiekunom 474 dzieci, w 2014 roku 1359 (Informacja Rady Ministrów 2014).

Niewłaściwe sprawowanie władzy rodzicielskiej, wymagające interwencji sądu, najczęściej przejawia się w zaniedbywaniu dziecka, pozostawianiu bez opieki, uporczywym niezaspokajaniu jego potrzeb biologicznych, emocjonalnych i społecznych czy zaniechaniu realizacji obowiązku szkolnego. Do ingerencji sądu we władzę rodzicielską najczęściej dochodzi na wniosek instytucji edukacyjnych, pomocy społecznej lub policji, zaniepokojonych sytuacją dziecka, którego dobro może być zagrożone, a podejmowane działania interwencyjne wobec rodziców okazały się nieskuteczne. Jak wskazuje Dobroniega Trawkowska (2010), rodziny, w których dochodzi do interwencji są przeważnie specyficzną kategorią rodzin problemowych określanych mianem rodziny „z marginesu społecznego”, „patologicznej”, „dysfunkcyjnej”, „wieloproblemowej” czy „specjalnej troski”.

Sąd przeważnie podejmuje kolejną próbę poprawy sytuacji przez poddanie wykonywania władzy rodzicielskiej nadzorowi kuratora sądowego, który przy współpracy z innymi instytucjami realizuje działania resocjalizacyjne wobec rodziców. Statystyki Wymiaru Sprawiedliwości (2014) wskazują, że jest to najczęściej stosowane rozwiązanie. W 2013 roku nadzór kuratora sądowego nad wykonywaniem władzy rodzicielskiej orzekany był przez sądy rodzinne wobec rodziców 133 940 dzieci, co stanowiło 68\% spraw dotyczących małoletnich. 
Umieszczenie w pieczy zastępczej jest rozwiązaniem stosunkowo rzadko stosowanym i wynika $\mathrm{z}$ troski o dobro dziecka oraz uwzględnienia zasady subsydiarności oraz prymatu rodziny $\mathrm{w}$ wychowaniu. $\mathrm{Z}$ zasady następuje po stwierdzeniu nieprawidłowego sprawowania przez rodziców władzy rodzicielskiej drastycznie godzącego w prawa i interesy dziecka. Decyzja sądu najczęściej wynika z braku poprawy lub pogorszenia się sytuacji rodzinnej i ma na celu zagwarantowanie dziecku kompensację skutków braku właściwej opieki ze strony rodziny. Umieszczenie w pieczy zastępczej traktowane jest jako ostateczne rozwiązanie gwarantujące dziecku bezpieczeństwo i stabilny rozwój. Kończy etap działań resocjalizacyjnych podejmowanych przez kuratora sądowego wobec rodziny. W 2013 roku w rodzinach zastępczych przebywało $22 \%$ małoletnich będących pod opieką sądów, a $10 \%$ umieszczono w placówkach opiekuńczo-wychowawczych (Wymiar Sprawiedliwości 2014). Maria Kolankiewicz i Monika Rożen (2011, s. 99), porównując dane z Polski i innych krajów europejskich, ustaliły, że w 2010 roku wskaźnik instytucjonalizacji dzieci w Polsce wyniósł $0,93 \%$, co w porównaniu z innymi krajami okazało się wynikiem niskim.

Rodzina zastępcza lub instytucja opiekuńczo-wychowawcza jedynie przejmuje część zadań związanych z bieżącą opieką nad dzieckiem do czasu poprawy jego sytuacji rodzinnej. Pomimo umieszczenia dziecka w pieczy zastępczej rodzice przeważnie zachowują prawo do nieograniczonego kontaktu z dzieckiem i decydowania w sprawach dla niego istotnych.

Do końca XX wieku trzonem systemu instytucjonalnej opieki nad dziećmi pozbawionymi właściwiej opieki rodzicielskiej, zaniedbanymi wychowawczo, zagrożonymi niedostosowaniem i niedostosowanymi społecznie były domy dziecka. Wraz z pogotowiami opiekuńczymi, placówkami rewalidacyjnymi i resocjalizacyjnymi zapewniały właściwe środowisko wychowawcze, tworząc w obrębie systemu oświaty sieć instytucji opiekuńczo-wychowawczych. Bezpośrednio po drugiej wojnie światowej stały się schronieniem dla sierot, które utraciły rodziców w wyniku działań wojennych. W związku z opuszczeniem przez nie placówek większość wychowanków zaczęły stanowić dzieci z patologicznych środowisk, których rodzice nie wypełniali właściwie swoich obowiązków. W 1998 roku sieroty biologiczne stanowiły jedynie 5\% wszystkich wychowanków domów dziecka, zaś 95\% dzieci przebywało tam na podstawie decyzji sądu rodzinnego ingerującego we władzę rodzicielską (Czyż 2000). Od lat 60 . XX wieku wraz z rozwojem instytucji rodzicielstwa zastępczego malała również liczba dzieci w domach dziecka. Z czasem placówki te przestały być wiodącą instytucją zastępującą rodzinę. Obecnie pełnią funkcję pomocniczą, zapewniając opiekę dzieciom, wobec których inne formy nie mogły zostać zastosowane (por. Kelm 2000, s. 75). 
Zadaniem placówek opiekuńczo-wychowawczych było przygotowanie wychowanków do samodzielnego życia w społeczeństwie przez zapewnienie im poczucia bezpieczeństwa i stabilizacji życiowej, normalizację sytuacji rodzinnej oraz zaspokajanie potrzeb życiowych. Dom dziecka miał tworzyć środowisko wychowawcze sprzyjające wielostronnemu rozwojowi przez kształtowanie nawyków pracy, właściwego wykorzystywania czasu wolnego, wspieranie kształcenia ogólnego i zawodowego oraz pomaganie wychowankom w nabywaniu praktycznych umiejętności (por. Kelm 2000; Czeredrecka 1997; Wagner 1997). Do 2004 roku umieszczenie w placówce opiekuńczo-wychowawczej było również jednym ze środków wychowawczych wymienionych w Ustawie z dnia 26 października 1982 r. o postępowaniu w sprawach nieletnich (Rejzner 2013). Domy dziecka stanowiły bowiem istotny element systemu w ramach funkcjonującego w Polsce modelu postępowania z nieletnimi, określanego jako opiekuńczy czy paternalistyczny. Stawia on sobie za cel ochronę dziecka przed szkodliwymi wpływami społecznymi przez zagwarantowanie właściwych warunków do rozwoju (por. Stańdo-Kawecka 2007, s. 25-26).

Na początku XXI wieku w Polsce dominowały duże domy dziecka zapewniające opiekę 30-60 wychowankom. Wraz z przejęciem w 1999 roku placówek opiekuńczo-wychowawczych przez resort pomocy społecznej rozpoczęto realizację transformacji systemu opieki nad dzieckiem. Została ona poprzedzona kampanią medialną pod hasłem: „Zamknijmy domy dziecka”, w którą aktywnie włączyli się przedstawiciele wielu różnych środowisk. Zmiany wymuszała również konieczność dostosowania się do międzynarodowych standardów dotyczących praw człowieka (Andrzejewski 2009, 2012). Bezpośrednim bodźcem do zmian były m.in. regulacje mające związek z walką z przemocą wobec dzieci, młodzieży i kobiet (Decision of the European Parliament... 2000). Dla wielu osób stało się bowiem oczywiste, że umieszczanie dzieci w placówkach opiekuńczo-wychowawczych jest przemocą wobec nich i łamaniem ich praw: do życia w rodzinie, kontaktów z bliskimi, godności, poszanowania prywatności, ochrony przed przemocą.

Krytykowano kolektywny model wychowania i totalny charakter instytucji opiekuńczo-wychowawczych. Wcześniejszym rozwiązaniom zarzucano zbytnią medykalizację przez położenie głównego nacisku na działania korygujące i „rozwiązania specjalne”, prowadzące do naruszania praw człowieka. Skrytykowano je za koncentrację działań wyłącznie na dziecku, oderwany od lokalnych potrzeb centralny system finansowania i zarządzania oraz brak skorelowania działań z systemem pomocy społecznej odpowiedzialnym za pomoc rodzinie (Gudbrandsson 2006).

Postulowano podjęcie działań profilaktycznych obejmujących rodzinę i środowisko oraz wskazywano na potrzebę odejścia od wychowania instytucjonalnego przez likwidację dużych instytucji opiekuńczych, zastąpienie ich formami rodzinnymi oraz niewielkimi placówkami współpracującymi ze środowiskiem lokalnym. 
Proces deinstytucjonalizacji przyspieszył po 2004 roku w związku z integracją Polski z Unią Europejską (dalej zastosowany skrót UE) oraz zaleceniami Europejskiej Grupy Ekspertów ds. Przejścia od Opieki Instytucjonalnej do Opieki Świadczonej na Poziomie Lokalnych Społeczności (2012). Jako małe placówki opiekuńczo-wychowawcze określono miejsca gdzie przez co najmniej 3 miesiące przebywa od 11 do 24 wychowanków. Mniejsze środowiska zdefiniowane zostały jako placówki rodzinne. $\mathrm{Z}$ perspektywy wytycznych dotyczących instytucjonalizacji należało zatem większość funkcjonujących domów dziecka i pogotowi opiekuńczo-wychowawczych likwidować lub dostosować, ograniczając liczbę miejsc.

Po przejęciu placówek opiekuńczo-wychowawczych przez resort pomocy społecznej zainicjowano zmiany. Domy dziecka stały się placówkami socjalizacyjnymi, a pogotowia opiekuńcze interwencyjnymi. Ośrodki łączące obie funkcje zostały określone jako wielofunkcyjne. Zaczynając od poprawy standardów socjalno-bytowych, rozporządzeniami Ministra Pracy i Polityki Społecznej (MPiPS) w sprawie placówek opiekuńczo-wychowawczych ograniczono liczbę miejsc w ośrodkach do 60 (Rozporządzanie MPiPS z 1 września 2000 r.), a następnie do 30 (Rozporządzenie MPiPS z 19 października 2007 r.). Zmodernizowane placówki miały posiadać pokoje, w których mogło mieszkać nie więcej niż 5 wychowanków (na każdego miało przypadać minimum $5 \mathrm{~m}^{2}$ powierzchni), łazienki i toalety w ilości umożliwiającej korzystanie z nich w sposób higieniczny i zapewniający intymność, pomieszczenia do wypoczynku, miejsce do cichej nauki, kuchnię i aneksy kuchenne, jadalnię, pomieszczenia do zajęć terapeutycznych i sportowych, pokój gościnny, pokój dla dzieci chorych oraz ewentualnie gabinet pielęgniarski (Rozporządzanie MPiPS $z 1$ września 2000 r.).

Modernizacja placówek miała wiązać się z intensyfikacją działań wobec rodzin wychowanków, a tym spowodować zmniejszenie liczby dzieci w pieczy zastępczej. Nadrzędnym celem stała się reintegracja rodziny. Umieszczenie dziecka w placówce miało mieć charakter przejściowy i trwać do czasu zrealizowania interwencji kryzysowej, umożliwiającej jego powrót do domu. Nowoczesny dom dziecka miał być miejscem krótkoterminowej, profesjonalnej usługi polegającej na czasowym, zespołowym, terapeutycznym oddziaływaniu na dziecko i jego rodzinę w ramach określonego przez usługodawców planu (Polkowski 1999, s. 76). W przypadku braku możliwości współpracy z rodziną placówka opiekuńczo-wychowawcza miała zapewniać przejściową opiekę do momentu znalezienia dla dziecka miejsca w rodzinie adopcyjnej lub zastępczej, a w przypadku młodzieży starszej organizować działania usamodzielniające. Opieką instytucji miały być również objęte osoby wymagające specjalistycznych oddziaływań (rewalidacyjnych i resocjalizacyjnych), których potrzeb nie można było zaspokoić w środowisku rodzinnym (Polkowski 1999, s. 77). Planowanie i realizację działań wobec dziecka i rodziny powierzono 
wychowawcy, który jednoosobowo odpowiadał za dziecko. Jego pracę wspierać miał pedagog, psycholog, pracownik socjalny oraz inni specjaliści tworzący zespół do spraw okresowej oceny sytuacji dziecka.

Szybko okazało się, że zintensyfikowanie pracy z rodzinami nie przyczyniło się do powrotu wychowanków do domu. Brak spodziewanych efektów w postaci zmniejszenia liczby dzieci w pieczy zastępczej tłumaczono ogólnie złą kondycją polskich rodzin, wynikającą $\mathrm{z}$ destabilizacji i deinstytucjonalizacji rodziny a przejawiającą się dezintegracją rodziny, wzrastającą liczbą dzieci ze związków pozamałżeńskich i małżeństw rozwiedzionych, utrzymującym się dużym bezrobociem oraz wysokim wskaźnikiem emigracji zarobkowej do innych krajów UE. Przyczyn niezmniejszającego się zapotrzebowania na pieczę zastępczą doszukiwano się również w wadliwym funkcjonowaniu wymiaru sprawiedliwości zbyt pochopnie decydującego o odebraniu dziecka rodzicom.

W przypadku bardzo dużych placówek ich modernizacja często okazywała się zbyt kosztowana i wiązała się z redukcją miejsc. Powodowało to, że większość z nich nie osiągnęła w wyznaczonym czasie odpowiednich standardów. W przypadku nieletnich kierowanych do ośrodków resocjalizacyjnych i socjoterapeutycznych pogłębiło to problemy z realizacją postanowień sądów. W 2004 roku - po przekazaniu tych placówek resortowi edukacji - na jedno wolne miejsce w młodzieżowych ośrodkach wychowawczych czekało 2600 nieletnich, podczas gdy w tym czasie placówki te dysponowały jedynie 2783 miejscami (Laskowski 2007).

Dokonana w 2005 roku przez Józefa Hrynkiewicza kompleksowa analiza procesu kierowania dzieci do placówek opiekuńczo-wychowawczych uwidoczniła rzeczywiste przyczyny nieskuteczności przyjętych rozwiązań, tkwiące w logice funkcjonowania całego systemu. W podsumowaniu raportu autorka stwierdziła:

[...] system opieki zastępczej nad dzieckiem został wadliwie zaprojektowany w zakresie wszystkich narzędzi jego realizacji. Wykazano w nich wadliwie zaprojektowane rozwiązania prawne, finansowe, instytucjonalne, kadrowe oraz brak monitorowania i ewaluacji systemu. Punktem wyjścia dla projektowania systemu uczyniono kompetencje i uprawnienia insty tucji, a nie realizację głównego zadania, jakim jest opieka zastępcza nad dzieckiem. W stosunku do systemu, który został wadliwie zaprojektowany nie można, nawet po zrealizowaniu wnikliwych badań jakościowych, zgłosić rekomendacji, ponieważ to oznaczałoby, że obecnie istniejący system można naprawić (Hrynkiewicz 2006, s. 236).

Krytyka i brak spodziewanych efektów spowodował, że podjęto prace nad nową ustawą, która miała zminimalizować zagrożenie odebrania dziecka, zapewniając pomoc rodzinie. W założeniach do projektu ustawy o wspieraniu rodziny i systemie 
pieczy zastępczej nad dzieckiem (Założenia projektu... 2009) dokonano negatywnej oceny dotychczasowej opieki nad dzieckiem pozbawionym opieki rodziny. Jako przyczynę problemów wskazano koncentrację działań wyłącznie na dziecku oraz nadmierną łatwość umieszczania dzieci w pieczy zastępczej na podstawie przesłanek, które winny skłaniać do pracy socjalnej i wsparcia w środowisku rodzinnym. Wskazywano na brak mechanizmów motywujących gminy do pozostawienia dziecka w naturalnym środowisku, przekazywanie wychowanków z rodzin zastępczych do placówek opiekuńczo-wychowawczych oraz z placówek socjalizacyjnych do resocjalizacyjnych. Zwrócono również uwagę na narastający problem umieszczania dzieci z ośrodków opiekuńczo-wychowawczych w szpitalach psychiatrycznych.

W 2011 roku ustawą o wspieraniu rodziny i systemie pieczy zastępczej (ustawa $\mathrm{z}$ dnia 9 czerwca 2011 r.) wprowadzono nowe rozwiązania mające - zdaniem jej twórców - spowodować powstrzymanie napływu wychowanków do placówek opiekuńczo-wychowawczych. Powołano nowe stanowisko - asystenta rodziny, który miał pracować bezpośrednio z zagrożonymi rodzinami. Podniesiono kwoty świadczeń dla rodzin zastępczych, co miało zachęcać do tworzenia tej formy pieczy zastępczej. Deinstytucjonalizacja pieczy zastępczej miała wiązać się z rozwojem rodzinnych form wsparcia.

Wprowadzenie nowych regulacji prawnych ponownie nie przyniosło oczekiwanej poprawy w postaci istotnego ograniczenia liczby dzieci wychowujących się w środowiskach zastępczych. Pomimo intensywnych kampanii promujących rodzicielstwo zastępcze nadal widoczny jest niedobór chętnych do pełnienia tej funkcji. W stosunku do stanu z 2000 roku w 2013 roku liczba rodzin zastępczych zmniejszyła się o 3\% (do 38 859). W tym czasie liczba przebywających w nich dzieci wzrosła o 9\% (do 55 317). Nadal dominowały rodziny tworzone przez osoby spokrewnione z dzieckiem, w których przebywało ponad 72\% dzieci znajdujących się $\mathrm{w}$ rodzinach zastępczych. Według Informacji Rady Ministrów o realizacji Ustawy $z$ dnia 9 czerwca 2011 r. o wspieraniu rodziny i systemie pieczy zastępczej (Informacja Rady Ministrów... 2014) w 2013 roku w 1882 rodzinach zastępczych zawodowych przebywało jedynie 6655 dzieci.

Niewystarczająca liczba rodzin zastępczych, w szczególności niespokrewnionych, sprzyja kierowaniu lub pozostawaniu dzieci w instytucjonalnych formach pomocy lub powierzaniu osobom nieposiadającym odpowiednich kompetencji. Najwyższa Izba Kontroli sprawdzająca w 2011 roku stan systemu pieczy zastępczej (NIK 2012) zgłosiła szereg zastrzeżeń wobec realizacji pieczy rodzinnej. Odnotowano wiele nieprawidłowości, np. pozostawianie dzieci w rodzinach zastępczych, gdzie występowała patologiczna atmosfera wychowawcza lub powierzanie osobom spokrewnionym mającym konflikty z prawem. 
Duże domy dziecka i pogotowia opiekuńczo-wychowawcze zostały zastąpione małymi 14-osobowymi placówkami opiekuńczo-wychowawczymi typu socjalizacyjnego, interwencyjnego lub specjalistyczno-terapeutycznego. W 2000 roku w 502 domach dziecka przebywało 18225 dzieci (dodatkowo funkcjonowało 55 pogotowi opiekuńczych dysponujących 2858 miejscami), a w 2013 w 946 placówkach (w tym interwencyjnych) przebywało łącznie 19096 wychowanków (GUS 2014).

Pomimo wysiłków mających doprowadzić do deinstytucjonalizacji opieki nad dziećmi odsetek małoletnich przebywających w placówkach opiekuńczo-wychowawczych w Polsce utrzymuje się na tym samym poziomie od połowy lat 80. XX wieku i wynosi 0,3\% populacji dzieci w wieku 0-17 lat. Spadkowi liczby dzieci w pieczy instytucjonalnej towarzyszył bowiem niż demograficzny.

Nadal występuje problem znalezienia wolnych miejsc w pieczy zastępczej. W 2013 roku nie zrealizowano 815 postanowień o umieszczeniu w placówkach opiekuńczo-wychowawczych i rodzinach zastępczych, z czego 473 dotyczyło umieszczenia dzieci w pieczy instytucjonalnej. Wykonalność postanowień sądów jest więc zbliżona do tej z 2000 roku, kiedy to niezrealizowanych zostało 826 postanowień, i znacznie lepsza niż w 2007 roku - wtedy nie znalazło się miejsce w pieczy zastępczej dla 1620 dzieci (GUS 2014).

Powrót dziecka do domu rodzinnego w wyniku starań rodziców i działań reintegracyjnych nadal jest zjawiskiem stosunkowo rzadkim, a liczba dzieci opuszczająca placówki opiekuńczo-wychowawcze przed usamodzielnieniem od 2007 roku systematycznie spada. W 2013 roku do „zresocjalizowanego środowiska rodzinnego" powróciło zaledwie 5\% wychowanków (GUS 2014). Pobyt w placówce opiekuńczo-wychowawczej nie sprzyja podejmowaniu działań na rzecz powrotu do rodziny. Wielu rodziców godzi się bowiem z przejęciem przez państwo kosztów i zadań związanych z opieką nad dziećmi i nie czyni starań w kierunku powrotu dzieci do domu (Hrynkiewicz 2006; Trawkowska 2010). Szybkim powrotem do domu nie są również zainteresowani sami wychowankowie. W pieczy zastępczej mają zagwarantowane znacznie lepsze warunki bytowe i standard opieki przy zachowaniu regularnych kontaktów z rodziną (Chudnicki, Maciejewska 2013). Świadczenia pieniężne związane z procesem usamodzielnienia przysługują pełnoletnim wychowankom opuszczającym placówki, a ich wysokość jest uzależniona od długości pobytu. W interesie wychowanka (i jego rodziny) jest więc pozostanie w placówce jak najdłużej. Powrotem dzieci do rodziców nie są również zainteresowane instytucje zaangażowane w proces umieszczania dziecka w placówce opiekuńczo-wychowawczej, gdyż zwiastuje to odradzanie się problemów, którym już raz zaradzono (Hrynkiewicz 2006).

Nadal nierozwiązany pozostaje problem przebywania małych dzieci w pieczy instytucjonalnej. Badania przeprowadzone w placówkach zajmujących się opieką 
nad dziećmi do 3 lat potwierdzały bowiem wiele negatywnych konsekwencji separacji od rodziców i pobytu w instytucjach (por. Browne i in. 2006; Browne i in. 2005). Mimo że nowe rozwiązania ustawowe teoretycznie ograniczają kierowanie dzieci poniżej 10. roku życia do placówek opiekuńczo-wychowawczych, to jednak, jak wynika z informacji Rady Ministrów o realizacji w roku 2012 Ustawy z dnia 9 czerwca 2011 r. o wspieraniu rodziny i systemie pieczy zastępczej, w 2012 roku w pieczy instytucjonalnej przebywało 2702 dzieci mających mniej niż 6 lat (Informacja Rady Ministrów... 2013).

Chociaż 2003 roku wyeliminowano placówki opiekuńczo-wychowawcze z katalogu środków wychowawczych wymienionych w ustawie o postępowaniu w sprawach nieletnich, nadal przebywają $\mathrm{w}$ nich dzieci kierowane do młodzieżowych ośrodków wychowawczych i młodzieżowych ośrodków socjoterapii. Według danych Centralnego Systemu Kierowania Nieletnich do Placówek Resocjalizacyjnych (Kaniowska 2011) w latach 2009-2010 nieletni z placówek opiekuńczo-wychowawczych stanowili 40,22\% wychowanków młodzieżowych ośrodków wychowawczych. Oddzielenie instytucji opiekuńczo-wychowawczych od systemu oświaty spowodowało, że umieszczenie nieletniego w placówce resocjalizacyjnej nie powoduje jego skreślania $\mathrm{z}$ listy wychowanków placówki socjalizacyjnej. Dodatkowo komplikuje to sytuację nieletniego oraz instytucji zaangażowanych w jego wychowanie. W 2008 roku w instytucjonalnej pieczy zastępczej przebywało 1850 wychowanków posiadających zasądzony środek w postaci umieszczenia w placówce resocjalizacyjnej (Stańdo-Kawecka 2009). Część wychowanków korzysta na co dzień z opieki innych instytucji: burs i internatów zakładów opieki leczniczej, oddziałów psychiatrycznych czy Ośrodków Szkolenia i Wychowania Ochotniczych Hufców Pracy.

Ograniczenie wielkości placówek, ich modernizacja i poprawa standardów socjalno-bytowych spowodowały podniesienie kosztów ich funkcjonowania. Zmusiło to instytucje finansujące do poszukiwania źródeł oszczędności, co odbiło się na bezpieczeństwie personelu i wychowanków oraz jakości realizowanych zadań. W latach 90. XX wieku 31\% wychowawców placówek opiekuńczo-wychowawczych w Polsce legitymowało się stażem ponad 20 lat pracy, a jedynie $9 \%$ stanowili nowi pedagodzy ze stażem 2-letnim (Kozdrowicz 1998). Zmiany warunków pracy i płacy spowodowały zatrudnianie osób niezainteresowanych pracą z dziećmi, które decydowały się na nią jedynie z powodu braku innych ofert na rynku. Nasiliło to rotację kadry i odpływ doświadczonych pracowników. Częste zmiany opiekunów są zjawiskiem niepożądanym, gdyż zakłócają proces wychowawczy, uniemożliwiając budowanie trwałych, pozytywnych więzi między wychowankiem a wychowawcą. Badania zrealizowane $\mathrm{w}$ ramach projektu Nawigator Zdobywców Przyszłości (Chudnicki, Maciejewska 2013) ujawniły, że ponad połowę kadry placówek 
opiekuńczo-wychowawczych objętych badaniami stanowiły osoby ze stażem krótszym niż 5 lat. Nowi pedagodzy pracują często samodzielnie, mając pod opieką do 14 wychowanków w różnym wieku i z różnymi problemami.

\section{PODSUMOWANIE}

Niewłaściwe sprawowanie władzy rodzicielskiej często niesłusznie utożsamiane jest $\mathrm{z}$ bezradnością wychowawczą, które, jak wskazuje Iwona Kudlińska (2011), jest pojęciem bardzo szerokim i odnosi się do różnych sytuacji życiowych. Mieszczą się w nim zarówno te rodziny, które potrzebują jedynie wsparcia, gdyż nie radzą sobie z opieką nad dziećmi z przyczyn niezależnych od siebie, jak i rodziny wymagające wsparcia połączonego z kontrolą, ponieważ ich dewiacyjny styl życia może zagrażać dzieciom, oraz takie, które w ogóle nie są w stanie sprawować opieki nad dziećmi.

Upatrywanie źródeł wzrostu liczby ingerencji sądów we władzę rodzicielską w coraz gorszej kondycji społeczeństwa i sprzyjającym nasileniu różnych patologii społecznych, rozkładzie rodziny, utrzymującym się wysokim bezrobociu czy wysokim wskaźniku emigracji zarobkowej wydaje się być zbyt dużym uproszczeniem. Dezintegracja rodziny, wzrastająca liczba dzieci ze związków pozamałżeńskich i rozbitych rodzin są pochodnymi procesów zachodzących od czterech dekad w rodzinach europejskich, i które można określić mianem destabilizacji i deinstytucjonalizacji rodziny. Składowymi tych procesów są: spadek częstotliwości zawierania małżeństw przy równoczesnym wzroście popularności związków nieformalnych, podejmowanie decyzji o związku małżeńskim w późniejszym wieku, niechęci do posiadania dzieci i opóźnieniu decyzji o urodzeniu dziecka, rosnąca liczba urodzeń poza małżeństwem, separacji i rozwodów (Kotowska 2013). Zmienia się również model rodziny z mężczyzną jako jedynym żywicielem na rzecz modelu $\mathrm{z}$ dwojgiem pracujących rodziców. Aby procesy te mogły przebiegać bezproblemowo potrzebna jest spójna polityka społeczna, umożliwiająca pogodzenie obowiązków rodzinnych, zawodowych oraz dająca bezpieczeństwo ekonomiczne rodzicom (flexicurity) (Durasiewicz 2013). Wydaje się, że jedynym konsekwentnie wspierającym obydwoje pracujących rodziców jest skandynawski model welfare state. Zdaniem Ryszarda Szarfenberga (2011, s. 148) w Polsce polityka rodzinna, a szczególnie ta część, która odpowiada za interwencję i pieczę zastępczą, stała się tematem dla mediów, zaś kierunki i dynamikę działań w większym stopniu wyznaczały doraźne cele polityczne niż jakiekolwiek badania naukowe.

Podejmowane próby administracyjnego ograniczania kierowania dzieci do placówek opiekuńczo-wychowawczych przez likwidację miejsc czy ograniczenia dotyczące sposobu orzekania o umieszczeniu w pieczy zastępczej nie spowodują 
zmniejszenia popytu na instytucje opiekuńczo-wychowawcze. Zapotrzebowanie na tę formę opieki wynika bowiem z potrzeb dziecka, które nie zostały zaspokojone przez inne instytucje mające za zadanie wspierać dziecko i rodzinę w ich środowisku. Wybór placówki nie jest więc alternatywą, lecz „złem koniecznym” wynikającym z nieskuteczności lub braku tych działań. Pomimo zmian, które dokonały się w placówkach opiekuńczo-wychowawczych, nadal pozostały one „[...] takim worem, do którego wpycha się wszystkie dzieci, z którymi nie ma, co zrobić (bo gdzieś przecież muszą być)" (Hrynkiewicz 2006). Dominującym typem ośrodków pozostała placówka socjalizacyjna przyjmująca dzieci z różnymi potrzebami. Dla samorządów ponoszących koszty tak zorganizowana piecza zastępcza jest rozwiązaniem tańszym i skuteczniejszym niż organizacja międzyresortowego, specjalistycznego i kompleksowego wsparcia dziecka i rodziny. Doświadczenia innych krajów (por. Power 2011) wskazują, że niższy koszt opieki instytucjonalnej wynika przede wszystkim z niewystarczających nakładów skutkujących niskim poziomem osiąganych wyników.

Brak skutecznego wsparcia dla rodzin i dzieci na poziomie lokalnym powoduje, że profesjonalną pomoc i wsparcie mogą uzyskać dopiero w wyspecjalizowanych instytucjach funkcjonujących na podstawie paradygmatu psychomedycznego. Świadczy o tym proces przepływu spraw z pomocy społecznej do sądów rodzinnych oraz umieszczanie wychowanków z placówek opiekuńczo-wychowawczych resortu pomocy społecznej do placówek specjalnych resortu edukacji, służby zdrowia czy wymiaru sprawiedliwości.

Brak obiektywnych kryteriów przesądzających o zastosowaniu konkretnego rozwiązania spotyka się z krytyką. Sprzyja bowiem łamaniu zasady subsydiarności i decyzjom arbitralnym naruszającym prawa dzieci i rodziców. Brak wsparcia w środowisku przy jednoczesnym ograniczaniu miejsc w placówkach opieki całkowitej nie tylko nie sprzyja integracji tych osób ze środowiskiem, lecz dodatkowo je wiktymizuje i kryminalizuje. Doświadczenia z innych krajów wskazują, że rolę likwidowanych instytucji opieki przejmują przytułki i zakłady karne, do których trafia coraz więcej osób chorych psychicznie otrzymujących wcześniej pomoc w instytucjach opieki całkowitej (Aderibigbe 1996). Potwierdza to rosnąca liczba osób niepełnosprawnych umysłowo i z zaburzeniami psychicznymi zarówno wśród przestępców, jak i ofiar przestępstw (Baldry 2008).

Państwo, starając się zapewnić dziecku optymalne wsparcie, powinno skierować je do wyspecjalizowanej instytucji, a spóźniona i nieprofesjonalna interwencja może mieć skutki odwrotne od zamierzonych (Marzec-Holka 1999). Aby działania w zakresie interwencji i pieczy zastępczej były efektywne i przejrzyste, powinny obejmować precyzyjny pomiar, selekcję oraz objęcie działaniami o potwierdzonej naukowo skuteczności (evidence based policy) (por. Szarfenberg 2011). Podejście 
to jest podstawą modelu RNR (risk-need-responsivity), który wśród zasad skutecznej interwencji korekcyjnej wymienia: 1) zasadę ryzyka, zgodnie z którą poziom intensywności oddziaływań powinien być uzależniony od nasilenia problemów, 2) zasadę potrzeb, która wskazuje, że interwencja powinna dotyczyć przede wszystkim czynników silnie skorelowanych z przestępczością, 3) zasadę reaktywności wskazującą, że działania powinny być dostosowane do możliwości osób (Andrews, Bonta 2007; Stańdo-Kawecka 2013; Looman, Abracen 2013). W ramach tego modelu zaleca się strukturalizowanie działań według oszacowanego na podstawie statycznych czynników ryzyka oraz koncentrację na czynnikach modyfikowalnych i dopasowanie interwencji do potrzeb osoby resocjalizowanej (Stańdo-Kawecka 2010; Andrews, Bonta 2007). Wydaje się niezbędne opracowanie w najbliższym czasie narzędzi aktuarialnych, które umożliwiłyby kuratorom sądowym precyzyjną identyfikację problemu i właściwe zaplanowanie działań wobec rodziców objętych kontrolą.

Na poziomie instytucjonalnej pieczy zastępczej pożądanym kierunkiem zmian powinno być zorganizowanie wielopoziomowej sieci placówek opiekuńczo-wychowawczych dysponujących zróżnicowaną ofertą w zakresie charakteru podejmowanych działań oraz długości pobytu dla dzieci w różnym wieku i z różnymi problemami. Powinny więc istnieć małe placówki dla dzieci i rodzin w kryzysie zintegrowane z szerszym systemem opieki i wsparcia rodziny. Ich nadrzędnym celem działania byłaby szybka reintegracja rodziny. Pełniąc rolę hostelu, zapewniałyby dzieciom krótkie, intensywne programy, okresową opiekę przy równoległej pracy nakierowanej na rodzinę oraz późniejsze wsparcie w środowisku.

W systemie powinny znaleźć się również placówki tworzące środowisko najbardziej zbliżone do rodzinnego i oferujące długoterminową opiekę. Nakierowane na zapewnienie dzieciom bezpiecznego i stabilnego środowiska wychowawczego oraz przygotowanie ich do samodzielności. Mogłyby do nich trafiać jedynie dzieci, których zachowanie nie zaburzałoby funkcjonowania całej społeczności.

Trzeci typ placówek powinny stanowić ośrodki specjalistyczne zapewniające intensywną i profesjonalną pomoc dzieciom krzywdzonym, zagrożonym niedostosowaniem społecznym, przejawiającym różne zaburzenia rozwojowe i niepełnosprawności oraz wymagającym specjalnej organizacji opieki i wychowania. Miałyby one oferować profesjonalną pomoc, wykorzystując precyzyjną diagnozę i odpowiednio przygotowaną kadrę. Pobyt w takich placówkach powinien mieć charakter turnusowy i ograniczony do czasu niezbędnego do realizacji programu terapeutycznego o naukowo potwierdzonej skuteczności.

Mimo braku regulacji prawnych promujących specjalizację instytucji opiekuńczo-wychowawczych oddolnie powoli następują zmiany w kierunku profesjonalizacji placówek opiekuńczo-wychowawczych. W latach 2013-2015 liczba ośrodków 
specjalistyczno-terapeutycznych zwiększyła się z 30 do 45 (Informacja Rady Ministrów... 2014). Wydaje się, że w obecnie skonstruowanym systemie zmiany te nie spowodują istotnej poprawy jakości pracy z dzieckiem umieszczonym w pieczy zastępczej. Brakuje bowiem instytucji diagnostyczno-kierującej, której zadaniem byłoby wskazanie placówki optymalnej pod względem potrzeb dziecka. Po przejęciu przez centra pomocy rodzinie kompetencji w zakresie kierowania do placówek opiekuńczo-wychowawczych wyboru miejsca pobytu dziecka dokonuje się najczęściej na podstawie informacji o dostępności miejsc i koszcie utrzymania wychowanka w poszczególnych placówkach.

Przy dalszej profesjonalizacji instytucjonalnej pieczy zastępczej niezbędne jest więc wyposażenie instytucji kierujących w narzędzia diagnostyczne określające optymalny z perspektywy potrzeb dziecka rodzaj instytucji opiekuńczo-wychowawczej.

\section{LITERATURA}

Aderibigbe Y.A., 1997, Deinstitutionalization and criminalization: tinkering in the interstices. "Forensic Science International", 85(2), 127-134.

Andrzejewski M., 2009, O (nie)zamykaniu domów dziecka. „Archiwum Kryminologii", t. XXIX-XXX.

Bonta J., Andrews D.A., 2007, Risk-need-responsivity model for offender assessment and rehabilitation. "Rehabilitation" 6, 1-22.

Baldry E., 2009, Prisons and vulnerable persons: Institutions and patriarchy. Australia and New Zealand Critical Criminology Conference 2009: Conference Proceedings, s. 18-30, opublikowano: https://www.researchgate.net/profile/ Alex_Steel/publication/43128227_Bail_in_Australia_legislative_introduction_ and_amendment_since_1970/links/0deec5267bca9afa80000000.pdf\#page=18 [dostęp: 11.10.2015].

Browne K., Hamilton-Giachritsis C., Johnson R., Ostergren M., 2006, Overuse of institutional care for children in Europe. "British Medical Journal" 332(7539), 485-487.

Browne K.D., Hamilton-Giachritsis C.E., Johnson R., Ostergren M., Leth I., Agathonos H., Anaut M., Herczog M., Keller-Hamela M., Klimackova A., Stan V., Zeytinoglu S., 2005, A European Survey of the number and characteristics of children less than three in residential care at risk of harm. "Adoption and Fostering", 29(4), 1-12. 
Chudnicki A., Maciejewska R., 2013, Analiza funkcjonowania placówek opiekuńczo-wychowawczych na terenie województwa podkarpackiego $w$ ramach projektu „Nawigator zdobywców przyszłości”. Lublin.

Czeredrecka B., 1997, Dom dziecka. W: J. Brągiel, S. Badora (red.), Formy pracy opiekuńczo-wychowawczej. Częstochowa, Wydawnictwo Wyższej Szkoły Pedagogicznej w Częstochowie.

Czyż E., 2000, Stan przestrzegania prawa wychowanków domów dziecka. Warszawa. Decision of the European Parliament and of the Council of 24 January 2000 adopting a programme of Community action (the Daphne programme) (2000 to 2003) on preventive measures to fight violence against children, young persons and women, No 293/2000/EC.

Durasiewicz A., 2013, Rola flexicurity w godzeniu życia zawodowego z rodzinnym. „Wrocławskie Studia Politologiczne”, nr 15, 18-37.

Europejska Grupa Ekspertów ds. Przejścia od Opieki Instytucjonalnej do Opieki świadczonej na poziomie Lokalnych Społeczności, 2012, Ogólnoeuropejskie wytyczne dotyczące przejścia od opieki instytucjonalnej do opieki świadczonej na poziomie lokalnych społeczności. Bruksela.

Grobel S., 2014, Władza rodzicielska. W: J.M. Łukasiewicz, S. Grobel, R. Łukasiewicz, J. Wiktor (red.), Instytucje prawa rodzinnego. Warszawa, Wolters Kluwer.

Gudbrandsson B., 2006, Dzieci w instytucjach opiekuńczych: zapobieganie instytucjonalizacji i alternatywne formy opieki w krajach europejskich, tłum. A. Nowak. „Dziecko Krzywdzone”, nr 17.

GUS, 2014, Pomoc społeczna i opieka nad dzieckiem i rodzina w 2013. Warszawa. Hrynkiewicz J., 2006, Odrzuceni. Analiza procesu umieszczania dzieci w placówkach opieki. Warszawa, Fundacja Instytutu Spraw Publicznych.

Informacja Rady Ministrów o realizacji w roku 2012 ustawy z dnia 9 czerwca 2011 r. o wspieraniu rodziny i systemie pieczy zastepczej (Dz. U. 2013, poz. 135, z późn. $\mathrm{zm}$.).

Informacja Rady Ministrów o realizacji w roku 2013 ustawy z dnia 9 czerwca 2011 r. o wspieraniu rodziny i systemie pieczy zastępczej (Dz. U. 2014, poz. 135, z późn. zm.).

Kaniowska T., 2011, Analiza zasadności umieszczania nieletnich w młodzieżowych ośrodkach wychowawczych i młodzieżowych ośrodkach socjoterapii. Warszawa, ORE, opublikowano: https://www.ore.edu.pl/materiay-do-pobrania-28973/ category/30-analizy-i-raporty?download=389:analiza-zasadnoci-umieszczanianieletnich-w-mow-i-mos. [dostęp: 13.09.2014].

Kelm A., 2000, Węzłowe problemy pedagogiki opiekuńczej. Warszawa, Żak. 
Kolankiewicz M., Rożen M., 2011, Dzieci poza rodzina. „Dziecko Krzywdzone”, t. 10, nr 3, opublikowane: http://fdn.pl/nr-3362011-dzieci-sie-licza-informacje-o-stanie-zagrozenia-bezpieczenstwa-i-rozwoju-dzieci-w-polsce [dostęp: 13.09.2014].

Kotowska I., 2014, Uwarunkowania zachowań prokreacyjnych. W: I. Kotowska (red.), Niska dzietność w Polsce w kontekście percepcji Polaków. Diagnoza społeczna 2013. Warszawa, Ministerstwo Pracy i Polityki Społecznej i Centrum Rozwoju Zasobów Ludzkich, opublikowano: http://www.diagnoza.com/pliki/raporty_tematyczne/Niska_dzietnosc_w_Polsce.pdf [dostęp: 10.09.2015].

Kozdrowicz E., 1998, System opieki nad dzieckiem opuszczonym. W: M. Kolankiewicz (red.), Zagrożone dzieciństwo. Rodzinne i instytucjonalne formy opieki. Warszawa, WSiP.

Kudlińska I., 2011, Społeczne konstruowanie roli (złej) matki - na przykładzie badań nad bezradnością opiekuńczo-wychowawcza. „Acta Universitatis Lodziensis", Folia Sociologica, nr 39.

Laskowski A., 2007, Centralny system kierowania nieletnich do placówek resocjalizacyjnych i socjoterapeutycznych. „Problemy Opiekuńczo-Wychowawcze”, $\mathrm{nr} 2$. Looman J., Abracen J., 2013, The Risk Need Responsivity Model of Offender Rehabilitation: Is There Really a Need For a Paradigm Shift?. "International Journal of Behavioral Consultation \& Therapy", 8(3).

Marzec Holka K., 1999, Nieletni przestępcy czynów karalnych przeciwko zdrowiu i życiu. W: H. Machel, K. Wszeborowki (red.), Psychospołeczne uwarunkowania zjawisk dewiacyjnych wśród młodzieży w okresie transformacji ustrojowej w Polsce. Gdańsk, Wydawnictwo Uniwersytetu Gdańskiego.

Ministerstwo Sprawiedliwości, 2014, Rocznik statystyczny sądownictwa powszechnego i wojskowego 2009-2013, Warszawa.

Najwyższa Izba Kontroli, 2012, Funkcjonowanie placówek opiekuńczo-wychowawczych oraz ich współdziałanie z innymi instytucjami na rzecz powrotu dzieci do wychowania $w$ rodzinie. Warszawa.

Polkowski T., 1999, Standardy usług opiekuńczo-wychowawczych. Warszawa.

Power A., 2011, Active Citizenship \& Disability: Learning Lessons in Transforming Support for Persons with Disabilities. Galway, National University of Ireland Galway.

Rejzner A., 2013, Polityka społeczna wobec dziecka i rodziny problemowej. W: B. Jezierska, A. Rejzner, P. Szczepaniak, A. Szecówka (red.), Profilaktyka społeczna i resocjalizacja w nurtach inkluzji. Doświadczenia, problemy, perspektywy międzynarodowe. Warszawa, Uniwersytet Warszawski. Instytut Profilaktyki Społecznej i Resocjalizacji, 17-31. 
Rozporzadzenie Ministra Pracy i Polityki Społecznej z dnia 1 września 2000 r. w sprawie placówek opiekuńczo-wychowawczych (Dz. U. 2000 Nr 80, poz. 900).

Rozporządzenie Ministra Pracy i Polityki Społecznej z dnia 19 października 2007 r. w sprawie placówek opiekuńczo-wychowawczych (Dz. U. 2007 Nr 201, poz. 1455).

Stańdo-Kawecka B., 2007, Prawo karne nieletnich. Od opieki do odpowiedzialności. Warszawa, Wolters Kluwer.

Stańdo-Kawecka B., 2009, Przestępczość nieletnich w latach 1990-2007 i problemy resocjalizacji nieletnich sprawców przestępstw. W: J. Szymańczak (red.), Dzieci z grup ryzyka. „Studia Biura Analiz Sejmowych”, nr 1 (17).

Stańdo-Kawecka B., 2010, O koncepcji resocjalizacji w polskiej literaturze naukowej polemicznie. „Probacja”, nr 1.

Stańdo-Kawecka B., 2013, Wykonywanie kary pozbawienia wolności z perspektywy współczesnej penologii. W: P. Szczepaniak (red.), Polski system penitencjarny: ujęcie integralno-kulturowe. Warszawa, Centralny Zarząd Służby Więziennej Ministerstwa Sprawiedliwości.

Szarfenberg R., 2011, Interwencja rodzinna i piecza zastępcza - pomiędzy mediami, polityka i dowodami. W: D. Trawkowska (red.), Pomoc społeczna wobec rodzin. Interdyscyplinarne rozważania o publicznej trosce o dziecko i rodzinę. Toruń, Wydawnictwo Akapit.

Trawkowska D., 2010, Dokąd zmierzamy? Socjologiczna analiza działań podejmowanych wobec rodzin wieloproblemowych przez pomoc społeczna. „Teologia i Moralność", t. 7, 33-44.

Ustawa $z$ dnia 29 lipca 2005 r. o przeciwdziałaniu przemocy $w$ rodzinie (Dz. U. 2005 $\mathrm{Nr} 180$, poz. 1493).

Ustawa z dnia 9 czerwca 2011 r. o wspieraniu rodziny i systemie pieczy zastępczej (Dz. U. 2011 Nr 149, poz. 887).

Wagner I., 1997, Sieroctwo społeczne - przyczyny, następstwa, formy kompensacji. Częstochowa.

Założenia projektu ustawy o wspieraniu rodziny i systemie pieczy zastępczej nad dzieckiem, 2009, Ministerstwo Pracy i Polityki Społecznej, opublikowano: http://www. mpips.gov.pl/userfiles/File/Departament\%20Swiadczen\%20Rodzinnych/A\%20 opieka\%20zastepcza/zalozenia\%20po\%20RM\%2030.06.pdf [dostęp 04.11.2015]. 
THE REFORM OF THE FOSTER CARE SYSTEM.

ASSUMPTIONS, REALITY, PERSPECTIVES

\begin{abstract}
The aim of the article is to present changes that took place in the $21^{\text {st }}$ century in the Polish institutional child care system. The author discusses changes in educational care facilities in respect of worldwide tendencies in the field of transformation from institutional care to the care provided at a local community level. The article shows the effects of current legal and organizational solutions. Lack of effective solutions in the sphere of social policy, which causes the increasing number of the juveniles in the custody of the courts, is shown as a cause of the constant (not diminishing) need for institutional care. The article also suggests a different organization of the institutional foster care system which includes, first of all, the needs of children placed in it.
\end{abstract}

Keywords: juvenile, foster care, educational care facilities 